\title{
The Connexin 37 (1019C $>$ T) Gene Polymorphism Is Associated With Subclinical Atherosclerosis in Women With Type 1 and 2 Diabetes and in Women With Central Obesity
}

\author{
J. PIŤHA ${ }^{1}$, J. A. HUBÁČEK ${ }^{1}$, P. PIŤHOVÁ ${ }^{2}$ \\ ${ }^{1}$ Institute for Clinical and Experimental Medicine, Prague, Czech Republic, ${ }^{2}$ Teaching Hospital \\ Motol, Second Medical School, Department of Medicine, Prague, Czech Republic
}

Received May 31, 2010

Accepted June 25, 2010

\begin{abstract}
Summary
The gene for connexin 37 ( $C \times 37)$ is considered to be one of the candidate genes for cardiovascular disease. We evaluated the association between Cx37 $(1019 \mathrm{C}>\mathrm{T})$ gene polymorphism (Pro319Ser) and ankle brachial blood pressure index (ABI) in women with type $1(n=178)$ and type $2(n=111)$ diabetes, and in women from general population $(n=862)$. All women were genotyped for $\mathrm{C} \times 37$ polymorphism. In addition to traditional cardiovascular risk factors, ABI was analyzed. In women with type 1 diabetes, ABI significantly decreased from TT to CC carriers ( $p$ for trend $=0.008$ ). A similar trend was seen in women with type 2 diabetes $(p=0.050)$ and in women with waist circumference above $75^{\text {th }}$ percentile $(94 \mathrm{~cm} ; n=208$ ) of the general population $(p=0.049)$. The gene for $\mathrm{C} \times 37$ was associated with subclinical atherosclerosis in women with type 1 and 2 diabetes and in women with advanced central obesity. The presence of $\mathrm{C}$ allele indicated increased risk.
\end{abstract}

\section{Key words}

Connexin 37 gene - Atherosclerosis - Ankle brachial indexwomen $\bullet$ Diabetes mellitus $\bullet$ Central obesity

\section{Corresponding author}

J. Pitha, Laboratory for Atherosclerosis Research, Institute for Clinical and Experimental Medicine, Vídeňská 1952/8, 140 21, Praha 4, Prague, Czech Republic. Fax + 0420241271574. E-mail: japi@medicon.cz

The possible role of gap junctions in the process of atherosclerosis has been recently a matter of debate. An important factor in atherosclerosis development could be the altered communication between endothelial cells, vascular smooth muscle cells, and macrophages. The protein Connexin 37 (Cx37) has been suggested as one of the main participants in these inter-cell communications (Burnier et al. 2009). The protein is a member of the Connexin family forming gap-junction channels and hemichannels, distinctively affecting permeability for various signaling molecules. The $1019 \mathrm{C}>\mathrm{T}$ polymorphism (Pro319Ser) of the Cx37 gene could change function of this protein and could be a possible accelerator of atherosclerosis and cardiovascular disease. The main mechanism proposed is the increased adhesion of macrophages to the vessel wall (Wong et al. 2006) and as recently described in the population of obese men, macrophages could play a complex role in the metabolic and inflammatory processes in humans including atherosclerosis (Broch et al. 2010). However, regarding association between this polymorphism and cardiovascular disease non-consistent data are presented (Yeh et al. 2001, Yamada et al. 2002, Hirashiki et al. 2003, Han et al. 2008)

Diabetes mellitus ranks among the strongest predictors of cardiovascular disease (Milicevic et al. 2008). In diabetic patients, smaller vessels are involved more extensively than in non-diabetic populations. Hypothetically, gap junctions could play a more important role in patients with diabetes and/or insulin resistance. Therefore, the gene for $\mathrm{Cx} 37$ could play important role in these populations.

We evaluated the association between the $\mathrm{Cx} 37$ gene polymorphism and ankle/brachial blood pressure 
Table 1. Ankle-brachial blood pressure index in women without and with advanced central obesity, and in women with type 2 and 1 diabetes stratified by the Connexin $37(1019 \mathrm{C}>\mathrm{T})$ gene polymorphism.

\begin{tabular}{lcccc}
\hline Connexin 37 gene & Type 1 diabetes & Type 2 diabetes & $\begin{array}{c}\text { General population } \\
\text { Waist }>\mathbf{9 4} \mathbf{~ c m}\end{array}$ & $\begin{array}{c}\text { General population } \\
\text { Waist }<\mathbf{9 4} \mathbf{~ c m}\end{array}$ \\
\hline$n(T T / C T / C C)$ & $18 / 79 / 81$ & $13 / 45 / 53$ & $21 / 97 / 90$ & $80 / 300 / 274$ \\
$\%$ & $10.1 / 44.4 / 45.5$ & $11.7 / 40.6 / 47.7$ & $10.1 / 46.6 / 43.3$ & $12.2 / 45.9 / 41.9$ \\
$T T$ & $1.07 \pm 0.12$ & $1.00 \pm 0.06$ & $1.05 \pm 0.11$ & $1.06 \pm 0.09$ \\
$C T$ & $1.01 \pm 0.11$ & $0.99 \pm 0.13$ & $1.06 \pm 0.09$ & $1.05 \pm 0.09$ \\
$C C$ & $0.98 \pm 0.12$ & $0.96 \pm 0.19$ & $1.03 \pm 0.08$ & $1.06 \pm 0.08$ \\
$p$ value for trend & 0.008 & 0.05 & 0.05 & 0.33 \\
\hline
\end{tabular}

Data are mean \pm S.D.

index (ABI) in women with type 1 and 2 diabetes and in women from the general population with markers of insulin resistance expressed as increased waist circumference.

Women with type $1(n=178)$ and type 2 diabetes $(n=111)$ were examined in one center with regard to the presence of cardiovascular risk factors, genetic markers of atherosclerosis and the presence of preclinical atherosclerosis including ABI. The only exclusion criterion was participant's age over 55 years and/or refusal to be included in the study. We also analyzed data from a random population sample of 874 women between 45-55 years old. The Institutional Ethical Committee approved the study and all participants signed informed consent forms.

All women were examined by identical protocol including a questionnaire focused on cardiovascular disease, cardiovascular risk factors, and treatment. In addition, anthropometric measurements (weight, height, waist and hip circumferences), and blood pressure measurements were obtained in the standard manner. Women with history of current and past regular smoking were defined as smokers. Body mass index was calculated as weight in kg over squared height in meters.

DNA was isolated from frozen EDTA blood (Miller et al. 1988). To genotype the C1019>T (Pro319>Ser) variant within Cx37 gene, oligonucleotides 5 CTGGACCCACCCCCTCAGAATGGCCAAAGA and 5 AGGAAGCCGTAGTGCCTGGTGG and restriction enzyme AasI (Fermentas, Lithuania) were used to distinguish the $\mathrm{T}$ (fragments of $240 \mathrm{bp}$ and $35 \mathrm{bp}$ ) and C (275 bp) alleles. A set of 24 samples was analyzed three times within 3 weeks with $100 \%$ confirmity.

ABI was calculated as the quotient of the mean of systolic blood pressures at four ankle arteries and the mean of systolic blood pressures of brachial arteries. Blood pressures were obtained in all arteries from all participating women. In women with type 1 and 2 diabetes, the measurements were done by continuouswave Doppler ultrasound device with $10 \mathrm{MHz}$ probe (SmartDop 50, Hadeco, Japan). In women from the general population, a continuous-wave Doppler ultrasound device with $10 \mathrm{MHz}$ probe (Sonovit SV-1, Schiller AG, Switzerland) was used.

Descriptive data are presented as percentages for categorical variables and means with standard deviation for continuous ones. The differences between carriers of different genotypes were analyzed as $\mathrm{p}$ for the trend in the case of continuous variables; for discrete variables a Fisher exact $\chi^{2}$ test was applied (STATA software). To define high risk women from the general population, the $75^{\text {th }}$ percentile value of given continuous risk factors (body mass index, waist circumference, fasting glycemia, plasma lipids) was used as the cut off point.

Observed frequencies were similar to the frequencies published previously in other Caucasian populations (Boerma et al. 1999, Horan et al. 2006, Collings et al. 2007, Lanfear et al. 2007) and did not significantly differ between groups under study (Table 1).

The mean age of women from the general population, in women with type 2 and type 1 diabetes was $50.0 \pm 2.7, \quad 48.9 \pm 7.3$, and $36.9 \pm 10.2$ years, respectively. The prevalence of smoking in women from general population, women with type 2 diabetes, and with type 1 diabetes was 49.9, 53.0, and $33.5 \%$, respectively. The mean duration of diabetes in women with type 2 and type 1 diabetes was $9.0 \pm 7.1$ and $15.7 \pm 9.6$ years, respectively. Prevalence of cardiovascular disease (ischemic heart disease, peripheral artery disease, and history of stroke) in women from the general population, 
in women with type 2 diabetes, and in women with type 1 diabetes type was 5.5, 31.9, and $19.7 \%$, respectively.

As summarized in the Table 1, ABI significantly decreased from $\mathrm{TT}$ to $\mathrm{CC}$ carriers in type 1 diabetes $(p=0.008)$. A similar trend was observed in type 2 diabetes $(\mathrm{p}=0.050)$. Additionally, we analyzed data from general population with a focus on the women at high risk for insulin resistance $\left(75^{\text {th }}\right.$ percentile cut point fasting glycemia, body mass index, waist circumference and plasma lipids). In women with waist circumference above $75^{\text {th }}$ percentile, i.e. above $94 \mathrm{~cm}(\mathrm{n}=208$; TT/CT/CC: $10.1 / 46.6 / 43.3 \%$ ), a significant trend of decreasing $\mathrm{ABI}$ from $\mathrm{TT}$ to $\mathrm{CC}$ carriers was found $(\mathrm{p}=0.049)$.

In addition, in women who reported the presence of impaired fasting glycemia and at the same time had fasting glycemia above $75^{\text {th }}$ percentile, i.e. above $5.5 \mathrm{mmol} / \mathrm{l}$, a similar trend of decreasing ABI from TT to $\mathrm{CC}$ carriers was observed $(\mathrm{p}=0.015)$. However, the number of these women was low (TT/ CT/ CC: 6/20/22).

No association between the $\mathrm{Cx} 37$ gene and other cardiovascular risk factors under study were found in women with type 1 diabetes and in women from the general population with increased waist circumference. In women with type 2 diabetes, we observed that age (TT, $\mathrm{CT}$, and $\mathrm{CC}$ : $47.5 \pm 8.8,47.5 \pm 7.4$, and 50.2 \pm 6.9 years; $\mathrm{p}$ for trend $=0.049)$ and HDL cholesterol $(\mathrm{TT}, \mathrm{CT}$, and $\mathrm{CC}$ : $1.45 \pm 0.67,1.32 \pm 0.42$, and $1.56 \pm 0.57 \mathrm{mmol} / \mathrm{l}$; $\mathrm{p}$ for trend $=0.050$ ) increased from $\mathrm{TT}$ to $\mathrm{CC}$ carriers. In women with a waist circumference bellow $75^{\text {th }}$ percentile, waist circumference increased from TT to $\mathrm{CC}$ carriers

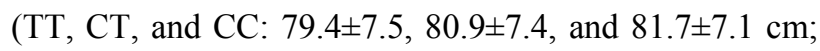
$\mathrm{p}$ for trend $=0.046$ ).

Based on our data, the gene for $\mathrm{Cx} 37$ was associated with preclinical atherosclerosis in women with type 1 and 2 diabetes and in women from the general population with advanced central obesity reflecting increased risk for insulin resistance. In all risk groups under study, the carriers of CC genotype had the lowest values of $\mathrm{ABI}$. While this association was weak in women with advanced obesity and women with type 2 diabetes, a very strong association was found in women with type 1diabetes. This indicates a possible important role of hyperglycemia as a strong modifier of $\mathrm{Cx} 37$ gene effect on macrovascular disease which could play important role especially in type 1 diabetes. Therefore, further confirmation of the hypothesis regarding the association between $\mathrm{Cx} 37$ genotype and the extent of macrovascular disease could be important for future studies.

\section{Conflict of Interest}

There is no conflict of interest.

\section{Acknowledgements}

Supported by grant NR/9026-4/2006 (Internal Grant Agency of the Ministry of Health of the Czech Republic).

\section{References}

BOERMA M, FORSBERG L, VAN ZEIJL L, MORGENSTERN R, DE FAIRE U, LEMNE C, ERLINGE D, THULIN T, HONG Y, COTGREAVE IA: A genetic polymorphism in Connexin 37 as a prognostic marker for atherosclerotic plaque development. J Intern Med 246: 211-218, 1999.

BROCH M, RAMÍREZ R, AUGUET MT, ALCAIDE MJ, AGUILAR C, GARCIA-ESPANA A, RICHART C: Macrophages are novel sites of expression and regulation of retinol binding protein-4 (RBP4). Physiol Res 59: 299-303, 2010.

BURNIER L, FONTANA P, ANGELILLO-SCHERRER A, KWAK BR: Intercellular communication in atherosclerosis. Physiology (Bethesda) 24: 36-44, 2009.

COLLINGS A, ISLAM MS, JUONALA M, RONTU R, KÄHÖNEN M, HUTRI-KÄHÖNEN N, LAITINEN T, MARNIEMI J, VIIKARI JS, RAITAKARI OT, LEHTIMÄKI TJ: Associations between connexin37 gene polymorphism and markers of subclinical atherosclerosis: the Cardiovascular Risk in Young Finns study. Atherosclerosis 195: 379-384, 2007.

HAN Y, XI S, ZHANG X, YAN C, YANG Y, KANG J: Association of connexin 37 gene polymorphisms with risk of coronary artery disease in northern Han Chinese. Cardiology 110: 260-265, 2008.

HIRASHIKI A, YAMADA Y, MURASE Y, SUZUKI Y, KATAOKA H, MORIMOTO Y, TAJIKA T, MUROHARA T, YOKOTA M: Association of gene polymorphisms with coronary artery disease in low- or high-risk subjects defined by conventional risk factors. J Am Coll Cardiol 42: 1429-1437, 2003. 
HORAN PG, ALLEN AR, PATTERSON CC, SPENCE MS, MCGLINCHEY PG, MCKEOWN P: The connexin 37 gene polymorphism and coronary artery disease in Ireland. Heart 92: 395-396, 2006.

LANFEAR DE, JONES PG, MARSH S, CRESCI S, SPERTUS JA, MCLEOD HL: Connexin37 (GJA4) genotype predicts survival after an acute coronary syndrome. Am Heart J 154: 561-566, 2007.

MILICEVIC Z, RAZ I, BEATTIE SD, CAMPAIGNE BN, SARWAT S, GROMNIAK E, KOWALSKA I, GALIC E, TAN M, HANEFELD M: Natural history of cardiovascular disease in patients with diabetes: role of hyperglycemia. Diabetes Care 31 (Suppl 2): S155-S160, 2008.

MILLER SA, DYKES DD, POLESKY HF: A simple salting out procedure for DNA extraction from human nucleated cells. Nucleic Acid Res 16: 1215, 1988.

YAMADA Y, IZAWA H, ICHIHARA S, TAKATSU F, ISHIHARA H, HIRAYAMA H, SONE T, TANAKA M, YOKOTA M: Prediction of the risk of myocardial infarction from polymorphisms in candidate genes. $N$ Engl $J$ Med 347: 1916-1923, 2002.

YEH HI, CHOU Y, LIU HF, CHANG SC, TSAI CH: Connexin 37 gene polymorphism and coronary artery disease in Taiwan. Int J Cardiol 81: 251-255, 2001.

WONG CW, CHRISTEN T, ROTH I, CHADJICHRISTOS CE, DEROUETTE JP, FOGLIA BF, CHANSON M, GOODENOUGH DA, KWAK BR: Connexin 37 protects against atherosclerosis by regulating monocyte adhesion. Nat Med 12: 950-954, 2006. 